\title{
OFFICIAL RUSSIA AND THE LITHUANIANS, 1863-1905*
}

\author{
THEODORE R. WEEKS
}

\begin{abstract}
The period between 1863 and 1914 in the Russian Empire is often described as one of 'russification'. In the case of the Lithuanians, this was a period characterized by the prohibition on publishing in the Lithuanian language in the Roman alphabet (until 1904). At the time and in later historiography, it has frequently been claimed that the Russian authorities aimed to russify the Lithuanian nation. However, a look at archival sources reveals that the reality behind the term 'russification' was less ambitious and far more contradictory. Rather than aiming at the ethnic extinction of the Lithuanians, the Russian authorities attempted (with very little success) to gain Lithuanian support for 'the Russian cause' against the Poles.
\end{abstract}

The study of Russia as a multinational Empire has grown in importance in recent years. With this growth of interest in such diverse national groups as Kazakhs, Estonians, Tatars and Kalmyks new efforts have arisen to grapple with the problem and definition of 'russification'. While few scholars would now endorse the rather crude thesis that the Russian government essentially aimed to wipe out all non-Russian cultures and replace them with Russian culture and the Orthodox religion, one can still encounter such arguments, particularly in nonspecialist works. While it is clear that the pre-revolutionary Russian government had neither the means nor even the desire to extirpate all non-Russian languages, cultures and religions, it is no less obvious that certain ethnicities were targeted by discriminatory laws that directly affected their capabilities for cultural development. In the Empire's western borderlands or zapadnyi krai after the failed uprising of 1863, Ukrainians and Belarusians were not recognized as

* The research and writing for this paper were supported by a short-term research grant at East European Studies, Woodrow Wilson International Center for Scholars, Washington, DC, and a grant from the International Research and Exchanges Board (IREX) with funds provided by the National Endowment for the Humanities, and the United States Department of State which administers the Title VIII Program. None of these organizations is responsible for the views expressed here. 
nationalities, but simply as branches of the Russian nation, and Polish, Jewish and Lithuanian cultures were subjected to severe restrictions. ${ }^{1}$

Here I would like to look at one example of 'russification' restrictions on Lithuanian culture and language in the decades between the Insurrection of 1863 and the Revolution of 1905. My purpose in this paper is not to recount the restrictions on Lithuanians during this period but to attempt to fathom the government's rationale in adopting anti-Lithuanian measures. In particular, the issue of 'russification' will be of central interest here and specifically the question: to what extent did the Russian government aim to culturally assimilate ('russify') the Lithuanians? From my readings of memoirs, official discussions within the Ministry of Internal Affairs (MVD), annual reports from the Lithuanian provinces (Kovno/Kaunas and Vilna/Vilnius), ${ }^{2}$ I conclude that while at certain moments Russian officials expressed a desire to see the region russified, when it came to attempting the cultural transformation of an entire population, they nearly always balked for both practical and ideological reasons. To be sure, this presents a contradiction: how could this 'eternally Russian land' (iskono-russkaia zemlia - a very typical phrase in the writings of nationally-minded officials) be 're-russified' without russifying the present inhabitants, Lithuanians, Poles, Jews and Belarusians? The contradiction was a very real one and reflects the gap between mythology ("eternally Russian land') and reality - cities dominated by Jews and Poles and a

${ }^{1}$ On national minorities and russification in the late Russian Empire there are a number of interesting recent works. See, for example: Andreas Kappeler, Rußland als Vielvölkerreich: Entstehung, Geschichte, Zerfall (Munich: Beck, 1992); Edward C. Thaden et al., Russification in the Baltic Provinces and Finland, 1855-1914 (Princeton: Princeton University Press, 1981); Daniel R. Brower and Edward J. Lazzerini, eds., Russia's Orient: Imperial Borderlands and Peoples, 1700-1917 (Bloomington: Indiana University Press, 1997); and, from a comparative perspective, Karen Barkey and Mark von Hagen, eds., After Empire: Multiethnic Societies and Nation-Building (Boulder: Westview, 1997). Specifically on the situation in the Western borderlands, see the quite different perspectives of Witold Rodkiewicz, Russian Nationality Policy in the Western Provinces of the Empire (1863-1905) (Lublin: Scientific Society of Lublin, 1998); and Theodore R. Weeks, Nation and State in Late Imperial Russia: Nationalism and Russification on the Western Frontier, 1863-1914 (DeKalb: Northern Illinois University Press, 1996).

${ }^{2}$ In general I will use the Russian forms of city names in this paper (e.g., 'Kovno' instead of Kowno or Kaunas, 'Vilna' instead of Wilno or Vilnius). This does not, of course, imply any recognition of Russian national claims here - Russians made up a tiny minority in this region - but reflects, rather, the fact that this paper concentrates on official mentalities and usage. 
countryside populated mainly by Lithuanians and Belarusians. Hence when speaking in broad, general terms mythology dominated, but when forced to deal with specifics (e.g., funding schools, enforcing restrictions), reality came to the fore. I will attempt to back up these rather general and dogmatic statements in what follows. The approach here will not be chronological, but thematic. Three themes will be examined, in each case through the lens of Russian officialdom: Lithuanians as 'potential Poles'; Lithuanians as 'potential Russians'; and Polish-Lithuanian tensions.

Before looking at these specific issues, it is necessary to consider one predominant and almost universal element of the official Russian mindset: a pervasive and at times almost hysterical fear and mistrust of things Polish and Catholic. One extreme example of this polonophobia is Ivan Aksakov, who saw Poles behind every sort of peasant disturbance, natural disaster or unrest, even in central Russia. ${ }^{3}$ And, to be sure, after the uprisings of 1831 and 1863, Russians were somewhat justified in viewing the Poles as hostile to the Russian state. The Russians blamed Polish landowners and townspeople for the excesses of 1863 , and even in areas where Lithuanian peasantry rose up against the Russians, official reports emphasized (correctly or incorrectly) the Polish leadership, often in the form of a priest. It would not be wrong to state that in the Northwest provinces (where practically all Lithuanians in the Empire resided) the Russian government viewed everything - culture, economy, military, religion as a battle between the 'Russian state principle' (russkaia gosudarstvennost) and 'Polonism'. In this 'battle' (the word borba often appears both in journalistic and official sources), Catholicism often became equated with Polonism. To quote Ivan Aksakov: 'from the very start, Catholicism appeared as an instrument of polonization' ${ }^{4}$ While the government never officially equated Catholicism and Polishness, on a practical level this is precisely what happened.

Lithuanians were caught in the middle of this 'struggle'. While their language and culture was demonstrably distinct from that of Slavic Poles or Russian, they were of course Catholics. The Catholic hierarchy in the region (indeed, throughout Russia) was heavily polonized, so that even those clerics of Lithuanian ethnicity would be trained in Polish as well as in Latin, and could even (especially before the 1860s) become

${ }^{3}$ See, for example, the essays collected in I. S. Aksakov, Pol'skii vopros i zapadnorusskoe delo. Evreiskii vopros. 1860-1886 (Moscow: Tip. M. G. Volchaninova, 1886).

${ }^{4} \mathrm{I}$. Aksakov, 'O znachenii katolitsizma v Zapadnom krae', Pol'skii vopros $i$ zapadno-russkoe delo, p. 425. The article was originally published in the journal Moskva on January 24, 1867. 
quite thoroughly polonized. While some attempts were made to distinguish between Catholics and Poles, on the whole the Russian authorities tended to agree that while the two categories were not entirely congruent, still there was considerable overlap. Only in the case of the Belarusian Catholics did Russian officialdom make a clear effort to distinguish between ethnicity and religion, in particular by attempting to introduce the Russian language in Catholic services. In any case, these efforts failed rather resoundingly. ${ }^{5}$ Only after 1905 does one again see a concerted effort to 're-claim' the Belarusian Catholics for the Russian nation. ${ }^{6}$ In the period under consideration in the Western provinces when Russian officials said 'Poles' they often meant all Catholics.

\section{Lithuanians as 'Potential Poles'}

The primary rationale for practically all Russian policy in the Northwest after 1863 was a desire to restrict Polish influence. In this way Lithuanians were more often than not regarded as passive objects of polonization. It is remarkable how seldom one encounters specific mention of Lithuanians in government reports and discussions from the period, though Poles (and Jews) come up nearly every time. There are several reasons for this 'silence'. First of all, the administrative units of the Russian Empire were not divided along lines of ethnicity. Hence, though the majority of the population of Kovno/Kaunas province was ethnically Lithuanian, there were also significant percentages of Lithuanians in neighboring Vilna/Vilnius province. ${ }^{7}$

${ }^{5}$ On this episode, see Theodore R. Weeks, 'Between Religion and Nationality: Attempts to Introduce Russian in the Catholic Churches of the "Northwest Provinces" after 1863', Między Odrq i Dnieprem. Wyznania i narody, vol. 2, ed. Tadeusz Stegner (Gdańsk: Wydawnictwo Uniwersytetu Gdańskiego, 1999).

${ }^{6}$ See, for example, Russian State Historical Archive, St. Petersburg (RGIA), f. 821 , op. 128,1912 , d. 697 ; and f. 821, op. 150, 1912, d. 167.

${ }^{7}$ For very detailed statistics from the 1897 census, see N. A. Troinitskii, ed., Pervaia vseobshchaia perepis' naseleniia Rossiiskoi Imperii (St. Petersburg: Tsentral'nyi statisticheskii komitet MVD, 1899-1904), 89 vols. For our purposes most important are volumes 4 (Vilenskaia guberniia) and 27 (Kovenskaia guberniia). According to the 1897 census, $68.3 \%$ of the population of Kovno province was Lithuanian (with 13.8\% Jewish, 9.0 Polish, and 7.3\% Russian); Lithuanians made up 17.6\% of Vilna province; Obshchii svod po Imperii rezul 'tatov razrabotki dannykh Pervoi Vseobshchei perepisi naseleniia, proizvedennoi 28 ianvaria 1897 g. (St. Petersburg, 1905), vol. 2, p. 65. For a discussion of statistics on native language and religion in Vil'na, Kovno and Grodno provinces, see A.B. [Aleksandr Beletskii?], 'Veroispovedanie i rodnoi iazyk korennogo naseleniia Vilenskoi, Kovenskoi i Grodnenskoi gubernii, po dannym perepisi 1897 goda', Vilenskii kalendar' na 1906 god (Vil'na: 'Russkii pochin', 1905), pp. 29-36. 
Furthermore, while Lithuanians made up the majority of the population in Kovno province, towns were predominantly Polish or Jewish. Russian administrators spent their time mainly in towns and were thus more poorly informed about the situation in the countryside. Perhaps most important, Lithuanians - unlike Poles or Jews - were not generally seen as a problem, hence administrators were less likely to mention them in their reports.

The administrative boundaries of the Northwest provinces also tended to minimize the apparent importance of Lithuanians. The governor general of Vilna was the head administrator of a very large region consisting of six provinces (to use the Russian forms of their names: Vilna, Vitebsk, Grodno, Kovno, Minsk, Mogilev). Only in one of these provinces (Kovno) did Lithuanians predominate. In the five other provinces, though populations were very mixed, the Belarusian element was predominant. Of course, for tsarist administrators these were simply 'Russians' - the element to be protected from Polish and Catholic influences. Hence when administrators wrote in general terms, they emphasized the 'Russian' element, often juxtaposing it with the Polish. The Jews presented a separate but also 'menacing' group from the Russian point of view. Obsessed with these two ethnic groups, Russian officialdom tended to overlook Lithuanians. Even in the annual reports of the Kovno governor, more often than not the ethnonyms litovets (or $z$ hmud') do not appear. ${ }^{8}$ To be sure, when he would write 'peasant', this would nearly always correspond to 'Lithuanian', but the ethnicity is seldom emphasized (in stark opposition to the Polish landowners and townspeople).

When Lithuanians are mentioned, in particular before the 1890s, it is nearly always in the context of the Catholic Church and explicit or implicit polonization processes. Even before the 1863 insurrection, the MVD expressed concern that the Polish/Catholic rebels attempted to bring the rural population (selskoe naselenie) over to their side. ${ }^{9}$ Along similar lines, the governor general of Vilna, A. L. Potapov,

${ }^{8}$ I base this observation on the perusing of twenty annual reports (gubernatorskie otchety) from Kovno, 1863-1894. The Russian government continued to distinguish between 'Lithuanians' (litovtsy) and 'Samogitians' (zhmud'), even in the 1897 census. This distinction corresponds roughly to dialects spoken in eastern and west-central Lithuania. Another group of Lithuanians in the Russian Empire, residing in Suvalki (Suwalki) province of the Kingdom of Poland, will not be discussed here.

9 'Sostavlennyi v Ministerstve Vnutrennikh Del ocherk obshchago khoda del v zapadnom krae s nachala 1861 goda po konets 1862 goda', Sbornik dokumentov muzeia Grafa M. N. Murav'eva, ed. A. Beletskii, vol. 1 (Vil'na: Tip. 'Russkii pochin', 1906), pp. 14-15, 19. 
wrote in 1868 that in Kovno province the entire 'Samogitian' population was Catholic and fanatical, easily led astray by their polonizing clergy, which he characterized as "completely in the service of polonizing the Northwest country ... The past mutiny [i.e., 1863] found in them [the clergy] nearly its only firm support ... ${ }^{10}$ Indeed, the highest cleric in the region, Bishop Motiejus Valančius, came in for stern criticism as subversive, anti-government, pro-Polish and implicitly anti-Lithuanian. In particular the governor general criticized Valančius for allegedly refusing to allow the use of the Lithuanian language in the so-called 'supplemental religious service' (that is, sermons, hymns, prayers and the like - the liturgy was of course in Latin). This is particularly ironic given Valančius's own Lithuanian ethnic background (his name is always given in the polonized form Wołonczewski). ${ }^{11}$ It is also worthy of note that the governor general desired the use of Lithuanian in churches in Kovno province, or, to put it another way, wished that Polish was not used. These sentiments, both of the need to divide Catholicism from 'Polonism' and about the disloyal attitude of Bishop Valančius, are echoed in the Kovno governor's report for $1870 .{ }^{12}$

Three years later Potapov again criticized Valančius for propagating an anti-Russian and pro-Polish line within the local Catholic Church. The governor general insisted that he did everything possible to respect freedom of religion but that any measures aimed at reducing the anti-government activities of the clergy were immediately and falsely interpreted by the local population as a threat to the Catholic religion itself. Attempts to introduce the Russian language into Catholic churches of the Belarusian Minsk province had not been successful, and at all levels the clergy spread false rumors that the use of Russian would mean conversion to Orthodoxy. At the Catholic seminary in Kovno, he remarked bitterly, Polish continued to be used as the main language of instruction, despite specific and direct government orders to the contrary. Once again, Lithuanians are not mentioned specifically. ${ }^{13}$

${ }^{10}$ RGIA, f. 1263 , op. 4, d. 46, 11. 20-22.

${ }^{11}$ Ibid., 11. 23-25. On Valančius/Wołonczewski, see: H. Raczkowski, 'Życiorys s. p. Biskupa Zmujdzkiego Macieja Wołonczewskiego', no. 35-36, Przeglad Katolicki (1875), pp. 545-9, 561-4; and Antanas Alekna, Žemaičiu vyskupas Motiejus Valančius (Klaipeda: Šv. Kazimiero Draugijos Leidinys, 1922).

${ }^{12}$ RGIA, f. 1284, op. 69, 1871, d. 133, esp. 11. 23-24. The official interpretation of Bishop Valančius as pro-Polish is particularly interesting given his sincere commitment to extending the use of Lithuanian within local Catholic churches. See, for example, Egidijus Aleksandravičius and Antanas Kulakauskas, Caru valdžioje. Lietuva XIX amžiuje (Vilnius: Baltos lankos, 1996), esp. pp. 163-180: 'Valančiaus epocha: lietuvybès kelias ì Bažnyčiq ir Bažnyčios posūkis i lietuvybę’.

${ }^{13}$ RGIA, f. 1263 , op. 1, 1874, d. 3723, 11. 29-31, 36-45. 
Over ten years and three governors general later, the situation had not changed significantly. In 1886 governor general I. S. Kakhanov complained that many small incidents proved that 'certain parts of the population are far from giving up Polish nationalist aspirations and in the depth of their souls are always ready to behave with hostility toward all things Russian' ${ }^{14}$ As before, the governor general bewailed the continuing attempts by the Roman Catholic clergy to polonize the country, though he admitted that since 1864 Catholic priests behaved with more circumspection and caution. In particular Kakhanov objected to the use of Polish in those Catholic churches where Poles did not form a majority of the congregation. He went so far as to advocate the radical measure of forbidding the use of Polish, except in the churches in Polish-dominated areas. In this way, he noted, priests would be obliged to use 'instead of Polish, the Belarusian, Lithuanian, or Samogitian [zhmudskoe] dialect'. ${ }^{15}$ In other words, Kakhanov, who was well known as a Russian nationalist, indeed 'russifier', had no interest or plans in introducing the Russian language in these parishes, but did feel strongly that the use of Polish was not a religious but political tool to assimilate the peasant masses to Polish culture, thereby alienating them from 'everything Russian'.

The governor of Kovno province, V. P. Melnitskii, emphasized a somewhat different trend. To be sure, he shared the general prejudice against Catholic priests ( $k s e n d z y)$, claiming that they spread rumors against government schools. He also noted that the ksendzy were far better-off than Orthodox priests, in particular because the local Catholic peasantry was quite prosperous and paid the Catholic clergy for the carrying out of baptisms, weddings, funerals and the like. His report struck a new note, however, when he mentioned that while Catholic priests are a polonizing element, the peasants no longer always accepted this: "there have been cases where the Lithuanian peasants demand sermons in the Lithuanian, not Polish, language'. Furthermore, as he pointed out, the majority of priests in the province were themselves of Lithuanian descent, the sons of prosperous peasants. Nonetheless, their origins did not always translate into a sympathy for Lithuanian nationalist demands. ${ }^{16}$ The frictions between Polish and Lithuanian languages in Catholic churches would appear more and more frequently in official documents from around the mid-1880s. Still, even in 1890 (and, indeed, into the twentieth century), reports

${ }^{14}$ RGIA, f. 1284 , op. 223,1886 , d. $186,11.3 v-4$. This is the governor general's report for the period January 14,1884 to August 1,1886 .

${ }^{15}$ Ibid., 1l. 60-69; quotation from 1. 69v.

${ }^{16}$ RGIA, f. 1284, op. 223, 1884, d. 170, 1l. 4, 18-20; quotation from 1. 19. 
would continue to emphasize that the Catholic clergy in any case pursued anti-Russian goals. To quote the Kovno governor's report of 1890, 'The Roman Catholic clergy takes a struggle [borba] based on religion and transfers it to the national arena, [in such matters as] language, attitudes toward local [Russian] administrative organs and the like. They have been so successful in transmitting this notion to the people [narod] that the Pole, Samogitian [zhmudin] or Lithuanian stands opposed to the Russian, and the Catholic to the Orthodoxy'. ${ }^{17}$ In other words, not the nationality itself but the Catholic religion was the implacable enemy of the Russian state and nation.

At the very end of the century, the energetic and thoroughly reactionary governor general V. N. Trotskii (whose name has entered history as the pseudonym of a Jewish socialist) was no less negative in his appraisal of the local Catholic clergy. In one report he defined 'our system [since 1863]' as 'the creation of a counterweight to Polish influence'. ${ }^{18}$ This system, he emphasized, had on the whole failed. The Catholic clergy continued to carry out anti-government propaganda and were aided in this by extremely devout and even fanatical Catholic women. Once again the nationality of these Catholics was not specified, but Trotskii did claim that any priest lacking enthusiasm for the Polish cause would be transferred from his parish or otherwise punished by the polonophile bishops. Only 15 percent of priests in the six provinces, he claimed, were not of Polish descent, a claim that runs counter to other sources, most likely because Trotskii was more interested in 'political' attitudes than ethnic origin. The seminaries continue to use Polish and to spread hatred for 'all things Russian' and Polish Catholics agitate against Russian schools. In passing, without any commentary, Trotskii remarked that besides 'secret Polish schools' there existed underground Lithuanian schools teaching literacy in that language (that is, in the Latin script). ${ }^{19}$ Again, not the Lithuanian language itself but its proximity to Polish-inspired anti-Russian attitudes caused Trotskii his greatest worries.

In all of these documents Lithuanians are regarded not as intrinsically hostile to Russian interests but as 'victims' of negative Polish/Catholic influences. In very many documents (in particular before the 1880s), moreover, Lithuanians simply disappear from view either under the rubric 'Catholic' or 'peasant'. To be sure, it is not

${ }^{17}$ RGIA, Chital'nyi zal, op. 1, d. 43 (otchet for Kovno guberniia, 1890).

${ }^{18}$ RGIA, f. 1282 , op. 3, 1900, d. 355, 1. 3 (governor general's report for 1900).

${ }^{19}$ RGIA, f. 1263 , op. 2, st. 253-332, d. 5385, 1l. 588-608 (governor general's otchet for 1898). 
always easy to differentiate between the general dislike of Russian officials for Catholics and their somewhat less hostile regard for Lithuanians as a nationality. Still, it is significant that time and again governors and governors general spoke in favor of using the Lithuanian language (at least in Catholic church services). The main enemy of the Russian state interests (interestingly, the adjective russkii is almost invariably used, even where one might expect rossiiskii) and the Russian people was seen either in Catholicism itself, or in 'Polonism' and Poles, but rarely if ever in the Lithuanians.

\section{Lithuanians as 'Potential Russians'}

Did, then, official policy aim to assimilate Lithuanians into Russian culture or 'russify' them? No easy answer can be given to this question. Certainly, policies such as forbidding the use of Lithuanian in schools and of printing Lithuanian in Latin letters would appear to support such a contention. On the other hand, we have seen that quite often Russian officials seemed to have little problem with the use of the Lithuanian language, at least in its spoken form. It must also be remembered that St. Petersburg paid little attention to the Lithuanians per se after the initial repressions of the mid- and late$1860 \mathrm{~s}$. By the end of the nineteenth century even Russian officials noted the need for a more flexible policy toward the use of Lithuanian. In their reports and discussions of the future of this 'country', Russian officials seldom referred specifically to russifying Lithuanians. They did, however, emphasize the need to russify the region. Once again we find a seeming contradiction that depends primarily on a given official's focus. Taking the 'Northwest country' (Severo-zapadnyi krai) as a whole, one could plausibly argue (if one accepts the contemporary notion that Belarusians are Russians) that the predominance of Russian culture and language could be restored here. This would not necessarily preclude the continued existence, on a local level, of Polish, Lithuanian or Jewish cultures. One cannot prove that Russian officials aimed at a 'total russification' of these cultures, nor can one prove the opposite. It is significant, however, that Russians (official or otherwise) rarely specifically advocated the russification of Lithuanians (or Poles - Jews are another matter entirely). As we will see in the following examples, they emphasized instead the need toneutralize anti-Russian elements, to tie 'the land' to Russia, and to strengthen the Russian element (including local Belarusian peasants) here.

Even before 1863, local administrators had stressed the need to strengthen Russian culture and the Orthodox Church in the Northwest provinces. Already in 1831 M. N. Murav'ev, later to achieve notoriety as 'Murav'ev the Hangman' because of his brutal repression 
of the 1863 revolt, advocated in a memorandum to the Tsar that at the very least all local administrators should be Russian (up to that time Poles had dominated there). Murav'ev also suggested that by wise policies the government could woo to their side 'Old Believers, Jews, Tatars, various foreigners and natives [inozemtsy, tuzemtsy], Calvinists and finally Prussian immigrants' as allies in the struggle against the Poles. ${ }^{20}$ Perhaps most remarkable about this listing of potential allies is that while the numerically minuscule Lithuanian Tatars are mentioned, Lithuanians are completely passed over. Perhaps they were meant under the general categories 'foreigners and natives', and perhaps Murav'ev simply excluded them as too closely linked with the Poles to be friendly to the Russian authorities. In any case, Murav'ev nowhere in this document argued that non-Russians should be 'russified' - though he certainly would not have been against such an outcome. He contented himself here with the demand that all local officials be of the Russian nationality, and in fact even this demand was not fulfilled until after 1863.

On the eve of the uprising the highest educational official in the region, Prince A. P. Shirinskii-Shakhmatov submitted to the Minister of Education a long memorandum on the "condition and needs of the Vilna educational district'. At the very outset, Shakhmatov emphasized the 'peculiarity' (osobennost') of the district, 'which is based primarily on the nationality of the [local] population'. Shakhmatov put forth a variety of measures which 'while promoting the development of overall enlightenment at the same time could also enable the strengthening of the predominance of the local Russian element [uprochenie gospodstva russkago elementa $v$ krae, emphasis in original]' ${ }^{21}$ Aside from such measures as improving the quality of teachers, Shakhmatov also touched on the issue of language of instruction in local schools. While he agreed that 'of course' the Russian language would be obligatory as a subject of study in all schools, 'there are, however, some areas where the introduction of teaching of the national, nonRussian, language [obuchenie iazyku narodnomu, ne russkomu]

${ }^{20}$ M. N. Murav'ev, 'Zapiska 1831 goda ob uchrezhdenii prilichnago grazhdanskago upravleniia v guberniiakh ot Pol'shi vozvrashchennykh i unichtozhenii nachal, naibolee sluzhivshikh k otchuzhdeniiu onykh ot Rossii' in 'Chetyre politicheskiia zapiski grafa Mikhaila Nikolaevicha Murav'eva Vilenskago', Russkii arkhiv (June 1885), pp. 175-186, quotation from p. 180.

21 'Predstavlenie popechitelia Vilenskago uchebnago okruga kniazia Shirinskago-Shakhmatova Ministru Narodnago Prosveshcheniia, grafu E. V. Putiatinu, o sostoianii i nuzhdakh Vilenskago uchebnago okruga' Sbornik dokumentov muzeia Grafa M. N. Murav'eva, p. 144. 
is necessary'. In particular in Kovno province it would be necessary to teach the 'Samogitian language' because, according to Shakhmatov, useful books and pamphlets were issued in that language, which was also used for sermons in local churches. Polish, on the other hand, should be allowed in Kovno province only in more advanced classes ( $v$ gimnaziiakh $i$ progimnaziiakh) since Polish was the language used by local landowners and civil servants (chinovniki). ${ }^{22}$ The practical need for instruction in these languages was thus admitted even by Shakhmatov who specifically called for the strengthening of Russian culture here.

After 1863, to be sure, there was a hardening of the official line taken toward non-Russians. M. N. Murav'ev took the lead in insisting on a pitiless repression of things Polish and a strong government policy to make clear the 'Russianness' of the land. In a report to the Tsar dated May 14, 1864, Murav'ev claimed that 5/6 of the Northwest's population was 'entirely Russian' and asked rhetorically how such a region could be considered Polish. The figure is of course quite absurd - Jews alone made up nearly one sixth of the population here, leaving aside Poles, Lithuanians, Latvians and others. This claim cannot be taken as reflecting ethnic realities in the region but rather Russian hopes and aspirations for the future. Aside from measures to restrict Polish culture, to forbid Poles (and even Russians with Catholic wives) from serving in government offices, and to increase salaries of Orthodox clergymen, Murav'ev also pointed out the need for educational reform. The government should open, in his words, 'the largest possible number of elementary schools [narodnykh shkol]' in both urban and rural areas. These schools would primarily be in the hand of the Orthodox clergy and would teach "principally Russian and Slavic literacy, basic arithmetic, prayers, and elementary teachings on the dogmas of the Orthodox faith ...' Under no circumstances should Polish be allowed in local schools, but one should 'introduce the teaching of Samogitian [zhmudskaia] literacy in Russian letters in all schools of Samogitia'. ${ }^{23}$ Once again no attempt is made to reconcile the contradiction between elementary schools run by Orthodox priests and Russian teachers (Murav'ev wanted teachers 'imported' from Central Russia) and teaching Lithuanian, even if in Cyrillic script. On the one hand even Murav'ev was realistic enough to recognize that Lithuanian children could not simply be taught in

${ }^{22}$ Ibid., p. 146.

${ }^{23}$ M. N. Murav'ev, 'Zapiska o nekotorykh voprosakh po ustroistvu SeveroZapadnogo kraia', Iz bumag Grafa M. N. Murav'eva, ed. S. D. Sheremetev (St. Petersburg: Stasiulevich, 1898), pp. 37-49, pp. 37 and 42. 
Russian, but on a practical level that was precisely what the government attempted to do, with predictably dismal results.

In the early 1870 s, Vilna governor general Potapov wrote that at the primary level instruction was only carried out in Russian, that most teachers were of the Russian nationality and under close supervision, and that the spread of education 'takes on ever greater dimensions'. Potapov never mentioned Lithuanians specifically (though the very detailed report of over 200 pages length does have specific sections on 'nobility' - read 'Poles' - and Jews) but did mention government attempts to strengthen the local Russian element by subsidizing Russian peasant immigration. Some 1371 Russian families had been settled in Kovno province but, as Potapov admitted, such settlers were adequate neither from a quality (i.e., as representatives of the Russian nationality) nor quantity point of view. ${ }^{24}$ In his next report, Potapov made specific reference to the utility of these schools in Kovno province in reducing the amount of Catholic 'fanaticism' there: 'only education of the younger generation in the Russian spirit and with Russian speech [s russkoiu rechiu] can promote somewhat the uniting of the people [ob'edinenie naroda] and the removal from them of harmful influences which under unfavorable influences can lead to confusion [volnenie] in the minds of the underdeveloped and credulous masses'. While admitting the difficulty 'at first' of using Russian to teach Lithuanian peasant children, Potapov insisted that in the end the malchik-zhmudin quickly picked up not only the Russian language but also songs, fairy tales, and an appreciation of belonging to a larger whole, the Russian Empire. ${ }^{25}$

Potapov's convoluted bureaucratese is not easy to interpret. Was he advocating the elimination of Lithuanian culture through education in Russian? While this interpretation cannot be entirely discounted, I think it more likely that his words aimed to show a benevolent and progressive pacification of the region under his wise stewardship. The reality of the situation, as governor general Trotskii pointed out a generation later, was that very few Lithuanian children were attending government schools at all - just over six percent in Kovno province in the late $1890 \mathrm{~s} .{ }^{26}$ Potapov's phrase nekotoroe $o b$ "edinenie naroda is far from clear. Only with great straining can one interpret this murky phrase as looking forward to total russification of Lithuanians. Rather, it seems more likely that Potapov had in mind

${ }^{24}$ RGIA, f. 1263 , op. 4, d. 46, 11. 50v, 76. This report covered the period 1868-1870 and was dated April 13, 1871.

${ }^{25}$ RGIA, f. 1263, op. 1, d. 3723, 11. 73-75. This report covers the years 1871-1873.

${ }^{26}$ RGIA, f. 1282, op. 3, 1900, d. 355, 1. 9. 
what the Kovno governor stated more clearly in his 1876 report: 'I am firmly convinced that for the achievement of moral merging of local people into one Russian family [nravstvennoe sliianie tuzemtsov $v$ odnu russkuiu sem'iu] it will be necessary to demonstrate to them that religious faith and [national] origin of members [of this family] will never deprive anyone of equal rights [ravnopravnost'] and that there will rather only be made a strict demarcation between those worthy [dostoinyi] and unworthy of bearing the glorious name of a loyal subject of the Russian Tsar' ${ }^{27}$ In other words, not faith or nationality but loyalty was the true criterion for inclusion in the 'Russian family'.

\section{Polish-Lithuanian Tensions}

As is well known, the Lithuanian national movement blossomed in the decades after 1863. By the 1880s at least many Lithuanians were no longer content to acquiesce to either Polish or Russian cultural hegemony. For most Lithuanians, however, Polish culture seemed a great threat simply because it was closer than Russian. Polish landowners continued to dominate in Lithuanian-speaking areas even into the twentieth century and in towns such as Kovno and Wilno one was more likely to hear Polish (or Yiddish) than Lithuanian spoken. As Lithuanians came to demand their cultural rights, in particular in the Catholic churches of the region, relations between Poles and Lithuanians often showed signs of strain. Russian officials could hardly ignore these tensions, in particular when they led to public disturbances.

It is notoriously difficult to gauge exactly what was going on in the provinces of the Russian Empire, in particular in those regions populated by non-Russians. However, it seems clear that the use of Lithuanian in churches was not rare in parishes in Kovno province even in the 1880s. Around that time, the Lithuanian national movement was gaining ground and finding significant support among the local peasantry whose general economic condition had improved in the past twenty years since emancipation. Using Miroslav Hroch's typology, the decades between 1880 and 1905 witnessed a shift from 'stage A', when small groups of intellectuals work to 'define' as it were the nation primarily in linguistic and scholarly works, to 'stage C', when the movement takes on a truly mass character. ${ }^{28}$ Indeed, Hroch's typology seems to be corroborated by archival evidence. By

${ }^{27}$ RGIA, f. 1284 , op. 69,1877 , d. $178,1.8 \mathrm{~V}$.

${ }^{28}$ Miroslav Hroch, Social Conditions of National Revival in Europe (Cambridge: Cambridge University Press, 1985), esp. chapter 12: 'A National Movement of the Belated Type: the Lithuanian Example'. Hroch bases these pages in large part on Michal Römer, Litwa. Studyum o odrodzeniu narodu litewskiego 
the end of the 1890s, one frequently encounters in official reports mention of clashes in Catholic churches between Polish and Lithuanian parishioners. All administrators agreed that such disturbances could not be allowed, in particular when they took place inside churches. As usual, the Russian administration were concerned above all with keeping the peace and preventing any sort of public disorder. Not surprisingly, in nearly every case the Russian officials favored the Lithuanian side over the Polish, even when condemning 'excesses' of which Lithuanian parishioners may have been guilty. Most would probably have agreed with Ivan Kornilov's statement in an 1896 article that nobody considers the use of Lithuanian in the churches of Kovno province of political significance because the Lithuanians (in contrast to the Poles) 'do not dream about the creation of a separate ... Lithuanian state and prudently [blagorazumno] limit their attention to familial and societal matters [blagoustroistvo] ${ }^{,}{ }^{29}$

Evidence of the Polish-Lithuanian conflict in Catholic churches began to appear in official documents in the 1890s, often when parishioners of mixed parishes sent petitions to St. Petersburg complaining of the use of one language or another. One example of such a petition was sent by three women of 'Lozdzei' parish of Sejny district, Suvalki (Suwalki) province in early 1898. The women complained that since 1896, local Lithuanian-speakers had prevented anyone from singing in Polish in the local churches, had broken windows in local Polish houses, and even had beaten one Pole to death with sticks. ${ }^{30}$ The provincial head of the gendarmes in Suvalk blamed such disturbances on the local bishop Anton Baranovski (Baranauskas), whom he characterized as a "fervent Lithuanian patriot" (iaryi litvoman) keenly interested in raising the level of Lithuanian national feeling in the province. ${ }^{31}$ In reaction to this letter,

(Lwów: Polsk. Tow. Nauk., 1908). For more contemporary accounts, see: Jonas Basanavičius et al., O języku polskim w kościołach Litwy, also published in Lithuanian as Apie lenku kalbq Lietuvos bažnyčiose (Kaunas: S. Banaičio spaustuvė, 1906); E. Balcewicz, Stosunki kościelne na Litwie. Listy otwarte księdza do księży (Munich: J. Zawadzki, 1905); and Hippolyt Korwin-Milewski, Observations sur le conflit des langues polnaise et lithuanienne dans le diocèse de Wilna (Paris: L. de Soye, 1913).

${ }^{29}$ I. Kornilov, 'O pol'skom iazyke v kostelakh Zapadnoi Rossii' in idem., Zadachi russkogo prosveshcheniia v ego proshlom i nastoiashchem. Sbornik statei (St. Petersburg: Tip. A. P. Lopukhina, 1902), p. 333. The essay was originally published in No. 44 (1896) of the journal Otgoloski. Kornilov served many years in the Vilna educational district.

${ }^{30}$ RGIA, f. 821, op. 2, 1897, d. 73, 11. 10-11.

${ }^{31}$ Ibid., 11. 15-17. 
the acting Minister of Internal Affairs, D. S. Sipiagin, wrote the governor general of Warsaw, Prince A. K. Imeretinskii regarding this matter: 'The present movement aimed at separating Lithuanians from Poles in itself can not be considered a phenomenon dangerous to our state interests and, to a certain extent, if held within limits, would be useful'. Nonetheless, the present disturbances were an indication that some of Baranovski's most zealous comrades-in-arms [spodvizhniki] were pushing things too quickly. Sipiagin concluded that the bishop should be warned to select his 'co-workers' more carefully in order to avoid further disturbances. ${ }^{32}$

Governor general Imeretinskii's appraisal of the situation differed little from Sipiagin's. Writing in a letter to the Minister he stated his opinion that this recent rise in national and cultural consciousness [among Lithuanians in Suvalki province] and the striving to liberate the Lithuanian folk [plemia] from polonization did not contradict state interests. The tasks of local governmental policy must be limited, in his opinion, to vigilant observation and timely prevention in this ethnic [plemennoi] and cultural struggle of any extreme [rezkie] manifestations of the national idea which could negatively affect [otrazitsia] public order and tranquillity.

Along these lines Imeretinskii sent a letter to Bishop Baranovskii asking him to work to prevent further disturbances and outbreaks of 'national hostility' in his diocese. ${ }^{33}$ In the following decade, and particularly after 1905 , such disturbances - or at least their discussion in the press and in official documents - became ever more frequent, but the position of Russian officialdom changed little. ${ }^{34}$ In essence, they were happy to see that the Lithuanians were actively opposing polonization and worried only about possible public disorders caused by over-zealous individuals.

This opinion is also reflected in the massive report for 1902 1903 of governor general of Vilna, Prince P. D. Sviatopolk-Mirskii. Mirskii pointed out that Lithuanian Catholics generally had sermons in their own language and were interested in national development. Echoing a common theme, the governor general emphasized the need to avoid equating 'Catholic' with 'Pole'. In particular now, as education was spreading among Lithuanians, it was necessary to recognize and welcome that movement. ${ }^{35}$ In the end, however, Mirskii appeared to

${ }^{32}$ Ibid., 11. 22-23. Sipiagin's letter is dated December 12, 1899.

${ }^{33}$ Ibid., 11. 24-28.

${ }^{34}$ On the Polish-Lithuanian conflict see, for example: RGIA, f. 821, op. 128, 1911, d. 36; ibid., 1912, d. 701; ibid., op. 150, 'posle 1911', d. 154; and LVIA, f. 378, BS 1910 , b. 78 .

${ }^{35}$ RGIA, f. 1284 , op. 190, d. 84B, 1l. 13v-14. 
doubt that the Lithuanians could survive as a distinct nationality. Because of their small numbers and lack of historical traditions, Mirskii argued, ultimately the Lithuanians would 'be absorbed into the general population of Russia' (voiti v obshchii sostav naseleniia Rossii). ${ }^{36}$ In the short run, that is, Lithuanians would liberate themselves from Polish influence but over time they would gradually become assimilated and grow more like Russians. Still, to argue that Mirskii had in mind complete cultural russification considerably oversteps the level of specificity in this document.

\section{Conclusions}

Attitudes of Russian officialdom toward the Lithuanians changed but little during the two generations separating the insurrection of 1863 from the revolution of 1905 . To be sure, by the end of this period official Russia was prepared to abandon its ill-considered restrictions on Lithuanian publishing. Nonetheless, the Lithuanians continued as before to be seen more as possible allies than as a potential danger to Russian interests. Little attention was paid to the national rights of the Lithuanians per se: the Russian government was interested rather in keeping the peace and - above all - keeping the Poles down. While officials time and again expressed their desire and efforts to strengthen the "Russian state principle" and Russian culture in this region, they rarely explicitly advocated russifying Lithuanians in the sense of depriving them of their native language and culture. On the other hand, the domination of the Russian culture and language was never challenged, and while Lithuanians might hope to keep their own language, they would have to be content with a subordinate position for their native culture within the Russian Empire as a whole.

Russian officials, despite some dynamic exceptions, tended generally to shy away from any fundamental change in policy in the Northwest territory. Far from pushing an aggressively russifying agenda, for all their patriot-Russian rhetoric they expended neither significant energy nor funds to translate their high-flown phrases about this 'eternally Russian land' into reality. The Russian obsession with the 'Polish danger' even into the twentieth century prevented the local administration from appreciating the strength of the Lithuanian movement. For the Lithuanians, the restrictions of this period encouraged the development of their own independent culture, depending neither on Polish nor on Russian examples. While few Lithuanians in 1904 could have foreseen the establishment of an independent state in the next decade, the cultural foundations for

${ }^{36}$ Ibid., 11. 38v-39. 
independence had been laid in the previous decades. Ironically the combination of repression and neglect in Russian policy toward the Lithuanians helped assure precisely the opposite outcome than that desired: the establishment of a strong, independent Lithuanian national movement.

\section{Author Details.}

Theodore R. Weeks is Associate Professor of History at Southern Illinois University at Carbondale (USA), where he teaches Russian, European and World history. He was born on the island of Okinawa (Japan) and educated in Europe and the USA. His research interests include nationality policy in the Russian Empire, relations between Russians and other nationality groups (especially Poles, Lithuanians, Belarusians, and Jews). At present he is working on a book on the roots of modern Polish antiSemitism.

Address: Department of History, Southern Illinois University at Carbondale, Carbondale, Ill., USA

Email: tadeusz@siu.edu

\section{OFICIALIOJI RUSIJA IR LIETUVIAI 1863-1905 METAIS}

Santrauka

\section{THEODORE R. WEEKS}

1863-1914 metų laikotarpis Rusijos imperijoje dažnai laikomas ,rusifikacijos“ periodu. Lietuvoje tai lietuviškos spaudos lotyniškais rašmenimis draudimo periodas (iki 1904 m.). Tuo metu ir vélesnèje istoriografijoje buvo dažnai teigiama, kad rusu administracija siekè surusinti lietuvių tautą. Tačiau archyvų medžiagos analizè rodo, kad iš tikrujų terminas ,rusifikacija “ reiškẻ ne tokią ambicingą ir gan prieštaringą politiką. Rusu valdžia siekè ne tiek nutautinti lietuvius, kiek igyti (labai nesèkmingai) jų paramą „rusiškame reikale“, carinei administracijai konfrontuojant su lenkais.

Received 6 April 2000 